\title{
DISTINCTION BETWEEN DEVELOPING AND RESERVE FOLLICLES IN THE CYCLIC HAMSTER
}

\author{
G. S. GREENWALD \\ Departments of Obstetrics and Gynecology and Anatomy, \\ University of Kansas Medical Center, \\ Kansas City, Kansas 66103 (U.S. A.)
}

\section{SUMMARY}

It is postulated that at the beginning of the estrous cycle (day I) of the hamster each ovary has Io developing follicles and that an additional 25 veserve follicles can be recruited by graded doses of PMS. The 20 developing follicles (both ovaries combined) are prevented from ovulating when a single injection of I5 or 30 IU PMS is given on day 3, associated with a lengthening of the cycle to 7 days. When PMS treated hamsters are hypophysectomized at 1300 on day 1 , Io to 20 follicles are subtracted from the ovulation rate induced by injecting $5 \mu \mathrm{g} \mathrm{LH}$ on day 4 . Similarly primed animals hypophysectomized on day 2 , however, ovulate approximately the same number of eggs as intact PMS treated hamsters. This suggests that the pituitary must be in situ throughout most of day $I$ to stimulate the developing follicles but thereafter they can be maintained by PMS.

An antiserum (AS) to PMS prevents the development and maturation of the reserve follicles when administered as a single IP injection on either days I to 3 of the cycle of PMS treated hamsters. Injecting AS on day 3 results in a consistent delay of one day in completion of the cycle. Treatment with PMS ( 15 to $60 \mathrm{IU}$ ) causes a remarkable increase in peripheral levels of estrogen but the normal 4 day duration of the cycle is maintained with $r_{5}$ or 30 IU PMS. Injection of AS on day 3 at 0900 to hamsters primed with 30 or 60 IU PMS leads to a drastic curtailment in estrogen levels. The drop in estrogen levels is not as severe in intact hamsters injected with $\mathbf{r}_{5}$ IU PMS but it is manifested in similarly treated hypophysectomized hamsters. It is suggested that in the presence of high peripheral levels of estrogen only the reserve follicles secrete the hormone.

About ten years ago, I began to publish the results of experiments involving the manipulation of follicular development in the cyclic hamster (for a review article, see GREENWALD, I972). The endpoints used were the number of ovulations, determined by counting tubal ova, and histological analysis of the number of antral 
follicles developing on previous days of the cycle. Variables explored included the effects of unilateral ovariectomy, effects of injecting pregnant mares serum (PMS) on different days of the cycle and reversal of the actions of PMS by administering a specific antiserum.

Based on these experimental manipulations a series of models were proposed to account for follicular development in the cyclic hamster. In essence, the models proposed that in the untreated hamster, each ovary shortly after ovulation (day I of the cycle) has approximately Io preantral follicles capable of maturing into antral stages. These follicles are designated as developing follicles and they grow under the influence of endogenous gonadotrophins. Between days 3 and 4 (proestrus) of the cycle the number of developing follicles in each ovary is halved by atresia accounting for the normal ovulation rate of ro ova. However, if one ovary is removed at 0900 on days I to 3 of the cycle, all of the developing follicles in the remaining ovary are maintained, resulting in the ovulation of the number of eggs characteristic of the species. In addition to the group of developing follicles regulated by endogenous gonadotrophins, an additional population of smaller follicles termed reserve follicles are recruited by increasing doses of exogenous gonadotrophins. The maximal number of follicles capable of ovulating in one cycle is 70 eggs. Expressed differently, this represents Io developing and 25 reserve follicles per ovary. By various treatments, it is possible to dissociate the two sets of follicles and ovulate one group or the other.

The present study was designed to explore some of the questions raised by the previous investigations. In particular, the objectives were to determine : the effects of administering 5 to 60 IU PMS on superovulation (previous emphasis was on 30 IU or more of the hormone) ; the effects of hypophysectomy $(\overline{\mathrm{H}})$ on the ovulatory response of PMS-primed hamsters (does $\overline{\mathrm{H}}$ at different stages of the cycle eliminate the developing follicles?) ; the influence of an antiserum to PMS on ovulation (how long does PMS have to be present to mature the reserve follicles?) ; estrogen levels in PMS and antiserum treated hamsters (can the very high estrogen levels in normal hamsters be even further elevated by the presence of growing reserve follicles?).

\section{MATERIALS AND METHODS}

Golden hamsters (Mesocricetus auratus) were maintained on $\mathrm{a} \mathrm{I}_{4} \mathrm{~h}$ light: $10 \mathrm{~h}$ dark schedule (lights on : 0500-I 700). At least three consecutive 4 day cycles were recorded before the animals were used. The conspicuous post-ovulatory vaginal discharge (day I) was used to date the cycle ; day 4 corresponds to proestrus.

Pregnant mares serum (PMS ; Ayerst) was injected SC at 0900 on various days of the cycle ; the PMS was given as a single injection in $0.1 \mathrm{ml}$ physiological saline. The oviducts were flushed with saline to recover newly ovulated eggs and the surrounding granulosa cell mass was dispersed with hyaluronidase. Hypophysectomies, when performed, were carried out via the parapharyngeal approach with sodium pentobarbital as the anesthetic agent.

An antiserum (AS) to PMS was provided by Dr. Donald C. Johnson. Preliminary results indicated that the ability of 15 IU PMS (injected at day I) to ovulate 30-40 ova was abolished by the concurrent intraperitoneal injection of $25 \mu \mathrm{l}$ of the antiserum and the animals ovulated IoI 2 eggs after a normal 4 day cycle. Injection of non PMS-treated hamsters on days I-4 with $25 \mu 1$ of AS failed to alter cycle length or number of ovulations. In view of these results, this dose and route of administration of antiserum was used in all experiments. 
Estrone $\left(E_{1}\right)$ and estradiol $\left(E_{2}\right)$ were measured in peripheral plasma by radioimmunoassay. Details and validation of the RIA are provided in a recent paper (BARANCzUK and GEenwaLD, 1973). Additional details on experimental design are discussed at appropriate points in the text.

\section{RESULTS AND DISCUSSION}

\section{Effects of 5-60 IU PMS on ovulation and cycle length}

When various doses of PMS were injected on day $\mathrm{I}$ of the cycle, a seasonal variation in ovulation was noted depending on whether the animals were injected during the winter (December-February) or spring-summer periods (fig. I). This was

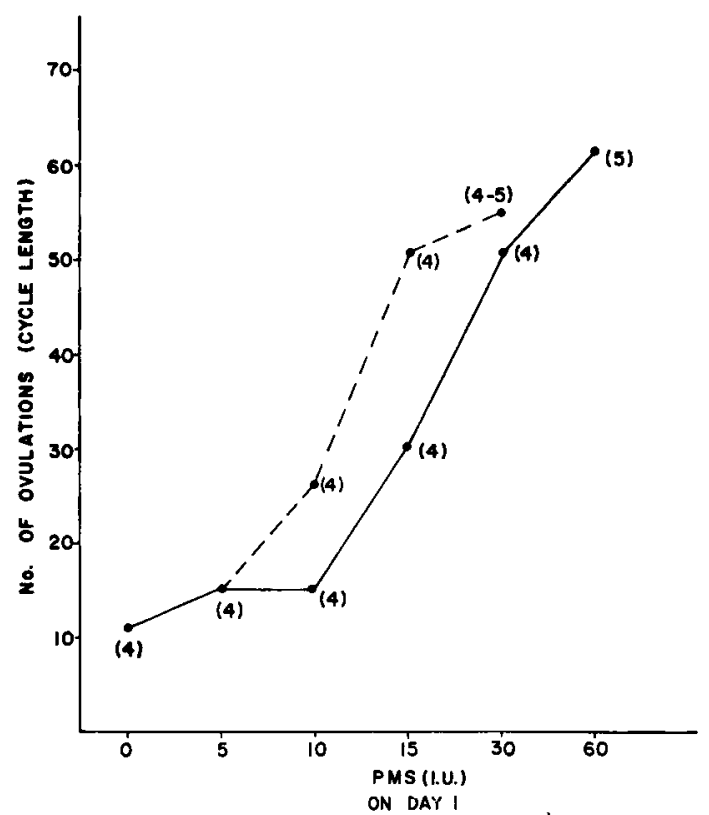

Fig. I. - Average no. of ovulations following a single SC injection of PMS at day 1 of the cycle Solid line indicates results during winter months; interrupted line shows results during spring-summer. Number in parenthesis is cycle length in days

FIG. I. - Nombre moyen d'ovulations après une injection sous-cutanee de PMS au jour 1 du cycle

résultats obtenus en hiver,
(- résultats obtenus au printemps-été,
$\quad$ ) durée du cycle en jours.

especially evident with Io IU PMS. Because of these temporal changes in ovarian responsiveness to PMS it was necessary to include appropriate controls in all experiments. With doses up to 30 IU PMS, the rigid 4 day cycle was maintained even though the animals ovulated 50 eggs. Treatment, however, with 60 IU PMS lengthened the cycle to 5 days.

The next step was to determine how ovulation and cycle length were affected 
by varying the day of PMS treatment (table $\mathrm{I}$ ). Cycle length was unaltered by shifting the day of injection of 5 IU PMS but ovulation was significantly reduced when the PMS was injected on day 4 as opposed to day $\mathbf{r}$. When the single injection

TABLE I

Effect of Varying the Day of PMS Administration

Effet de la dose et du jour d'administration de la PMS

\begin{tabular}{|c|c|c|c|}
\hline $\begin{array}{l}\text { Dose } \\
\text { of PMS }\end{array}$ & $\begin{array}{c}\text { Day } \\
\text { Given }\end{array}$ & $\begin{array}{l}\text { Mean no. } \\
\text { Ovulations } \\
( \pm \text { SEM) }\end{array}$ & $\begin{array}{c}\text { Length } \\
\text { of Cycle } \\
\text { (Days) }\end{array}$ \\
\hline $5 \mathrm{IU}$ & $\begin{array}{l}1 \\
2 \\
3 \\
4\end{array}$ & $\begin{array}{l}14.8 \pm 0.6(4) \\
15.3 \pm 2.4(4) \\
13.8 \pm 0.9(4) \\
11.8 \pm 0.6(4)\end{array}$ & $\begin{array}{l}4 \\
4 \\
4 \\
4\end{array}$ \\
\hline $15 \mathrm{IU}$ & $\begin{array}{l}1 \\
2 \\
3 \\
4 \\
4^{*}\end{array}$ & $\begin{array}{l}41.1 \pm 2.7(8) \\
28.9 \pm 2.3(8) \\
19.7 \pm 2.3(7) \\
10.5 \pm 1.0(4) \\
15.5 \pm 1.6(8)\end{array}$ & $\begin{array}{c}4 \\
4-5 \\
7 \\
4 \\
4\end{array}$ \\
\hline $30 \mathrm{IU}$ & $\begin{array}{l}1 \\
2 \\
3 \\
4 \\
4 *\end{array}$ & $\begin{array}{l}53.9 \pm 2.1(8) \\
51.4 \pm 4.2(7) \\
35.5 \pm 3.7(8) \\
11.8 \pm 1.0(4) \\
35.3 \pm 4.0(6)\end{array}$ & $\begin{array}{l}4 \\
5 \\
7 \\
4 \\
4\end{array}$ \\
\hline
\end{tabular}

of I5 IU PMS was deferred until day 2, there was a slight prolongation of cycle length and the number of ovulations dropped approximately Io per animal. The most drastic effects were observed when I5 IU PMS was injected on day 3 ; ovulation was reduced by 20 ova and cycle length was extended to 7 days. Postponing the injection of 30 IU PMS to day 3, again resulted in the ovulation of 20 fewer ova and the lengthening of the cycle to 7 days. A noteworthy difference between treatment with I5 or 30 IU PMS on day 4 of the cycle was apparent when a cycle was skipped before killing the animals. In the latter case, the animals still superovulated at the end of the intervening cycle, evidently in response to the longer biological half-life of the higher dose of PMS.

The lengthening of the cycle and reduced ovulation when I5 or 30 IU PMS were injected on day 3 is explicable in terms of the models shown in figure 2. When I5 IU PMS is injected at day I, coordinated growth of ro developing and Io reserve follicles occurs in each ovary. However, when PMS treatment is shifted to day 3, the developing follicles are already large antral stages and their maturation is asynchronous with the newly recruited reserve group. Moreover, the PMS treatment, 
initiates a new 4 day cycle; its superimposition on the original one accounts for the cycle lengthening to 7 days. The net result of these two variables is that the developing follicles gradually become atretic and only the reserve follicles go on to

TREATMENT: $\quad$ DAY OF CYCLE
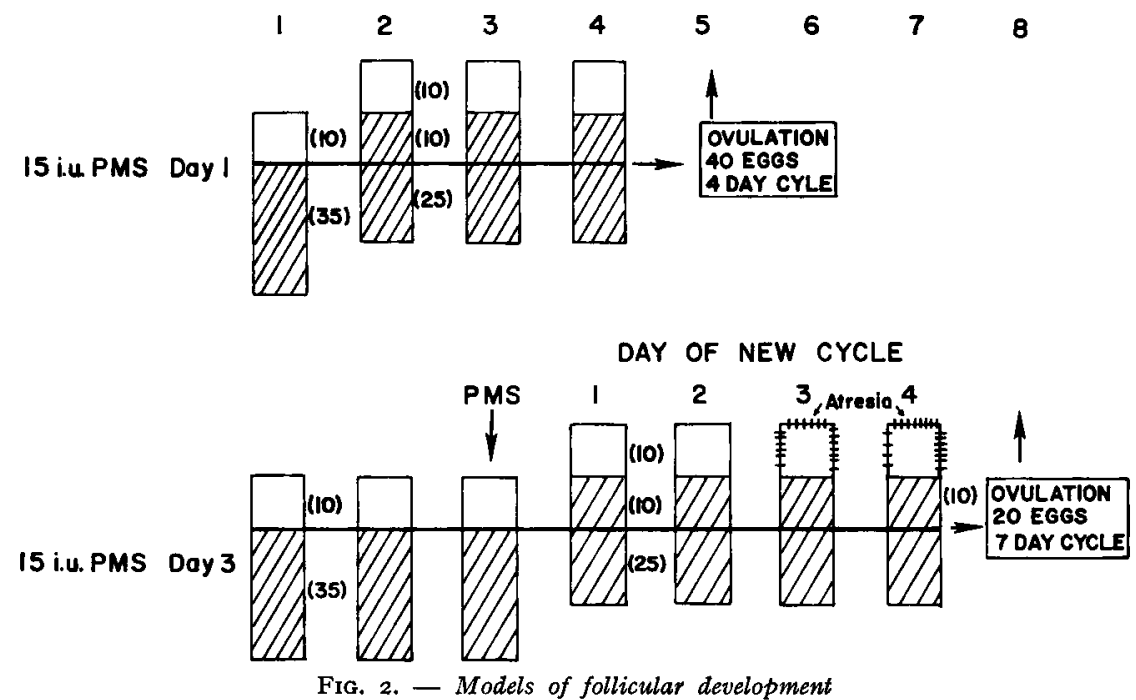

Clear box represents developing follicles; diagonally marked box represents reserve follicles

Fig. 2. - Modeles pour le développement folliculaire

Les carrés clairs représentent les follicules en développement, les carrés hachurés, les follicules de réserve

ovulate. A similar explanation accounts for the results when 30 IU PMS is injected on day 3 ; the only modification in the models is that more reserve follicles are recruited by the higher dose of PMS.

\section{Effects of hypophysectomy on PMS induced superovulation}

In the initial experiment, hamsters were injected at ogoo of day I with 5 to 6o IU PMS and hypophysectomized at I 300 on days $\mathrm{r}-4$. Ovulation was induced by the IP injection of $5 \mu \mathrm{g} \mathrm{LH}$ (NIH-S9) at I300 of day 4 ; the oviducts were flushed the next morning at ogoo to count newly ovulated ova. In the hypophysectomized hamsters 5 IU PMS was only sporadically effective in maintaining antral follicles (table 2). The results with Io IU PMS differed depending on whether the animals were injected during the winter or summer months. However, in both series, all animals ovulated in response to $\mathrm{LH}$. In the summer series, animals hypophysectomized on day I ovulated approximately ro fewer eggs than intact animals injected with Io IU PMS. This was also true of the group injected with I5 IU PMS. Very puzzling results were obtained when the animals were hypophysectomized on day 3 after receiving I5 IU PMS. The results of two experiments performed several months apart, are combined in table 2 . For the I5 IU PMS- 
primed group, animals hypophysectomized on day 3 consistently ovulated fewer ova and more animals were anovulatory than when the pituitary was removed on day 2 or 4 .

\section{TABLE 2}

Effect of Varying the Day of Hypophysectomy $(\overline{\mathrm{H}})$ on Ovulation ( $\left.{ }^{1}\right)$ in the Treated Hamsters

Effet du jour de l'hypophysectomie $(\overline{\mathrm{H}})$ sur l'ovulation chez les Hamsters traités

\begin{tabular}{|c|c|c|c|c|}
\hline $\begin{array}{l}\text { PMS (IU) } \\
\text { at Day } 1 \text { : }\end{array}$ & Treatment & \multicolumn{2}{|c|}{$\begin{array}{c}\text { Mean No. } \\
\text { Ovulations }( \pm \text { SE) }\end{array}$} & $\begin{array}{c}\text { No. Ovulating } \\
\text { Treated }\end{array}$ \\
\hline 0 & Intact & & $11.7 \pm .9$ & $6 / 6$ \\
\hline 5 & 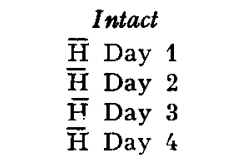 & & $\begin{array}{c}15.2 \pm 1.3 \\
2.5 \\
1.0 \\
2.0 \\
12.7 \pm .8\end{array}$ & $\begin{array}{l}6 / 6 \\
2 / 6 \\
1 / 6 \\
1 / 6 \\
6 / 6\end{array}$ \\
\hline 10 & \begin{tabular}{l}
\multicolumn{2}{c}{ Intact } \\
$\overline{\mathrm{H}}$ Day 1 \\
$\overline{\mathrm{H}}$ Day 2 \\
$\overline{\overline{\mathrm{H}}}$ Day 3 \\
$\overline{\overline{\mathrm{H}}}$ Day 4
\end{tabular} & $\begin{array}{c}\text { Winter } \\
15.2 \pm 1.3 \\
16.8 \pm 2.4 \\
14.5 \pm 3.5 \\
16.3 \pm 4.0 \\
16.0 \pm 1.8\end{array}$ & $\begin{array}{l}\text { Summer } \\
26.7 \pm 2.1 \\
19.0 \pm 1.7 \\
24.3 \pm 4.3 \\
26.0 \pm 3.3 \\
22.7 \pm 2.2\end{array}$ & $6 / 6$ each group \\
\hline 15 & \begin{tabular}{cc}
\multicolumn{2}{c}{ Intact } \\
$\overline{\mathrm{H}}$ Day 1 \\
$\overline{\mathrm{H}}$ & Day 2 \\
$\overline{\mathrm{H}}$ & Day 3 \\
$\overline{\mathrm{H}}$ & Day 4
\end{tabular} & & $\begin{array}{l}36.9 \pm 2.0 \\
23.4 \pm 3.0 \\
31.9 \pm 3.5 \\
14.2 \pm 3.3 \\
28.1 \pm 2.1\end{array}$ & $\begin{array}{l}15 / 15 \\
11 / 11 \\
11 / 11 \\
13 / 20 \\
13 / 13\end{array}$ \\
\hline 30 & $\begin{array}{c}\text { Intact } \\
\text { Intact }+5 \mu \mathrm{g} \text { LH } \\
\overline{\mathrm{H}} \text { Day } 1 \\
\overline{\mathrm{H}} \text { Day } 2 \\
\overline{\mathrm{H}} \text { Day } 3 \\
\overline{\mathrm{H}} \text { Day } 4\end{array}$ & & $\begin{array}{l}52.0 \pm 2.0 \\
50.8 \pm 2.1 \\
31.3 \pm 2.5 \\
49.7 \pm 4.5 \\
46.5 \pm 5.1 \\
52.0 \pm 6.9\end{array}$ & 6/6 each group \\
\hline 60 & \begin{tabular}{c}
\multicolumn{2}{c}{ Intact } \\
$\overline{\mathrm{H}} \quad$ Day 1 \\
$\overline{\mathrm{H}}$ Day 2 \\
$\overline{\mathrm{H}}$ Day 3 \\
$\overrightarrow{\mathrm{H}}$ Day 4
\end{tabular} & & $\begin{array}{l}62.8 \pm 2.2 \\
42.9 \pm 2.2 \\
52.8 \pm 5.4 \\
49.3 \pm 4.8 \\
63.7 \pm 5.3\end{array}$ & 6/6 each group \\
\hline
\end{tabular}

(1) $5 \mu \mathrm{g} \mathrm{LH}$ on day 4 at 1300 .

At this point I can only speculate on these unexpected results. The normal hamster ovulates 35 ova when injected with 20 IU human choronic gonadotrophin on day I2 of pregnancy (GREENWALD, I967). Thus, under some circumstances the hamster produces enough endogenous gonadotrophins to maintain three times the 
normal number of antral follicles. In the present experiment, the steroid levels resulting from I5 IU PMS possibly cause increased release of endogenous gonadotrophins on day 3 and a resultant follicular dependency on the native gonadotrophins. If the pituitary is removed on day 3 , the abrupt decline in gonadotrophins may result in the complete collapse of follicular development in some animals and reduced maintenance in others.

With either 30 or 60 IU PMS, hypophysectomy at day I subtracted approximately 20 eggs from the ovulation rate of the intact animal or from those hypophysectomized on days 2-4 of the cycle. In general, this was true of all of the groups ; hypophysectomy at I30o of day I resulted in significantly fewer ovulations than the other days of the cycle.

In the next related experiment, selected doses of PMS were injected at ogoo of day I but the time of hypophysectomy on day I was varied; ovulation was again induced by injecting $5 \mu \mathrm{g} \mathrm{LH}$ on day 4 (table 3 ). When the pituitary was removed at 0900 (i.e., the same time as PMS administration) ovulation was even more drastically curtailed especially in the group treated with ro IU PMS.

TABLE 3

Effect of Varying the Time of Hypophysectomy $(\overline{\mathrm{H}})$ on Ovulation (1)

Effet de l'heure de l'hypophysectomie $(\overline{\mathrm{H}})$ sur l'ovulation

\begin{tabular}{|c|c|c|c|}
\hline $\begin{array}{l}\text { PMS (IU) } \\
\text { at Day } 1 \\
(0900)\end{array}$ & $\begin{array}{l}\text { Time on } \\
\text { Day } 1 \text { of } \bar{H}\end{array}$ & $\frac{\text { No. Ovulating }}{\text { Total }}$ & $\begin{array}{c}\text { Mean No. } \\
\text { Ovulations } \\
( \pm S E)\end{array}$ \\
\hline $10 \mathrm{IU}$ & $\begin{array}{l}0900 \\
1300 \\
1700\end{array}$ & $\begin{array}{l}5 / 10 \\
6 / 6 \\
6 / 6\end{array}$ & $\begin{array}{r}7.3 \pm 2.3(5) \\
19.8 \pm 2.3(6) \\
21.0 \pm 1.8(6)\end{array}$ \\
\hline $15 \mathrm{IU}$ & $\begin{array}{l}0900 \\
1700\end{array}$ & $\begin{array}{l}6 / 6 \\
5 / 6\end{array}$ & $\begin{array}{l}16.7 \pm 3.8(6) \\
29.4 \pm 4.5(5)\end{array}$ \\
\hline $30 \mathrm{IU}$ & $\begin{array}{l}0900 \\
1700\end{array}$ & $\begin{array}{l}5 / 6 \\
5 / 6\end{array}$ & $\begin{array}{l}35.4 \pm 7.8(5) \\
44.8 \pm 1.7(5)\end{array}$ \\
\hline
\end{tabular}

(1) $5 \mu \mathrm{g} \mathrm{LH}$ on day 4 at 1300 .

Collectively, these experiments involving hypophysectomized animals are interpreted as follows. Impetus for further growth and differentiation of the developing follicles is initiated on day I of the cycle through a prolonged release of gonadotrophins (mainly FSH?). This is attested to by the fact that hypophysectomy at various times on day I eliminates ro to 20 follicles from maturing in the PMStreated animals. On the other hand, once the developing follicles have progressed far enough pituitary extirpation on day 2 or later does not result in their involution. Rather, they can now be maintained - along with the reserve follicles - by PMS. The one notable exception is the group injected with I5 IU PMS on day I and hypophysectomized on day 3 . 


\section{Effect of an antiserum (AS) to PMS on ovulation}

The experiments involving the effect of PMS antiserum are so extensive that they will be published in detail elsewhere; therefore, only a brief account will be given in this paper. The protocol consisted of injecting 5 to 60 IU PMS on day I at ogoo combined with a single IP injection of $25 \mu 1$ AS on either days I-4 (also at ogoo). The endpoint was the number of recently ovulated eggs recovered from the oviducts at 0900 on the completion of the cycle. As shown in table 4, the effects

TABLE 4

Effect of Varying the Day of Antiserum (AS) Administration

Effet du jour d'injection de l'antisérum (AS)

\begin{tabular}{|c|c|c|c|c|}
\hline \multirow{2}{*}{ Dose of PMS } & \multicolumn{4}{|c|}{ Mean No. Ovulations on Day 1 after AS at : } \\
\hline & Day 1 & Day 2 & Day 3 & Day 4 \\
\hline $5 \mathrm{IU}$ & $10.0 \pm 1.2(4)$ & $10.3 \pm 1.4(4)$ & $\begin{array}{c}0(4) \\
10.8 \pm 1.9(4) *\end{array}$ & $10.8 \pm 0.5(4)$ \\
\hline $10 \mathrm{IU}$ & $11.0 \pm 0.7(4)$ & $10.0 \pm 1.5(4)$ & $\begin{array}{c}0(4) \\
11.0 \pm 1.1(4)\end{array}$ & $\begin{array}{c}11.0 \pm 1.3(4) \\
\text { (winter) } \\
20.1 \pm 1.5(4) \\
\text { (spring) }\end{array}$ \\
\hline $15 \mathrm{IU}$ & $10.3 \pm 0.8(4)$ & $10.5 \pm 0.9(4)$ & $\begin{array}{c}0(4) \\
14.8 \pm 1.4(4)^{*}\end{array}$ & $31.8 \pm 3.8(8)$ \\
\hline $30 \mathrm{IU}$ & $11.8 \pm 0.8(4)$ & $10.0 \pm 0.8(4)$ & $\begin{array}{c}0(4) \\
13.3 \pm 1.3(3)^{*}\end{array}$ & $39.2 \pm 4.5(6)^{*}$ \\
\hline $60 \mathrm{IU}$ & $9.8 \pm 0.6(4)$ & $12.0(2)$ & $\begin{array}{c}0(4) \\
13.3 \pm 1.3(5)^{*}\end{array}$ & $17.3 \pm 6.4(3)^{* *}$ \\
\hline
\end{tabular}

* Oviducts flushed at day 2.

* Oviducts flushed at day 3 .

of PMS were cancelled in all groups when the AS was injected on day I or 2. However, after injecting AS on day 3 no animals ovulated on the anticipated day $I$; instead ovulation of IO-I5 eggs was delayed for one day. These results show that PMS is needed throughout the cycle to maintain the reserve follicles. When the AS was injected on day 4 , the hamsters primed with 5 to I5 IU PMS ovulated the next morning and the eggs were still enmeshed in granulosa cells. The same treatment of the 30 IU PMS group prevented ovulation by the next morning. However, by day 2 , large numbers of eggs were recovered from the oviducts but the ova were devoid of granulosa cells. This suggests that ovulation was delayed for less than a full day. The results were even more drastic when the AS was injected on day 4 into the 6o IU PMS primed group. In this instance, ovulation did not occur on the anticipated day I or 2 and only $50 \mathrm{p}$. roo of the animals ovulated by day 3 . 
In previous experiments (GREENWALD, I963) injection of $0.25 \mathrm{ml}$ AS on day 3 or 4 often completely blocked ovulation in animals given 60 IU PMS on day I, contrary to the one or two day delay observed in the present study with $25 \mu 1$ AS. Several groups of hamsters (primed with 30 or 6o IU PMS) were therefore administered $250 \mu 1 \mathrm{AS}$ on day 3. This treatment also deferred ovulation for only one day and the animals ovulated IO-I2 ova. The disparity from previous results (GREENWALD, I963) may represent a difference in the titer of antibodies raised to PMS in the experiments performed some ten years apart.

An intriguing point raised by the previous experiment was the consistent one day delay in ovulation in all PMS treated groups when AS was administered on day 3. We have recently shown that estrogen levels normally increase on day 3 of the hamster estrous cycle (BARANCzUK and GREENWALD, I973) and it was reasoned that sudden changes in estrogen levels, consequent on AS injection, might account for the lengthening of the cycle. Therefore, in the next experiment, estrogens were determined in PMS primed hamsters injected with either AS or saline.

\section{Estrogen levels in PMS primed intact or hypophysectomized hamsters}

Hamsters were injected with o, 5, I5, 30 or 6o IU PMS on day I (at 0900). The animals were either intact or hypophysectomized at 0900 . On the morning of day 3 (ogoo), they were injected with either $0.1 \mathrm{ml}$ physiological saline or $25 \mu \mathrm{AS}$ (in $0.1 \mathrm{ml}$ saline). At $\mathrm{I} 600$ of day 3 , the animals were bled via the abdominal aorta and plasma saved for estrogen determinations.

Changes in peripheral estrogen in intact animals induced by saline or AS administration on the morning (ogoo) of day 3 are summarized in figure 3 . It is apparent

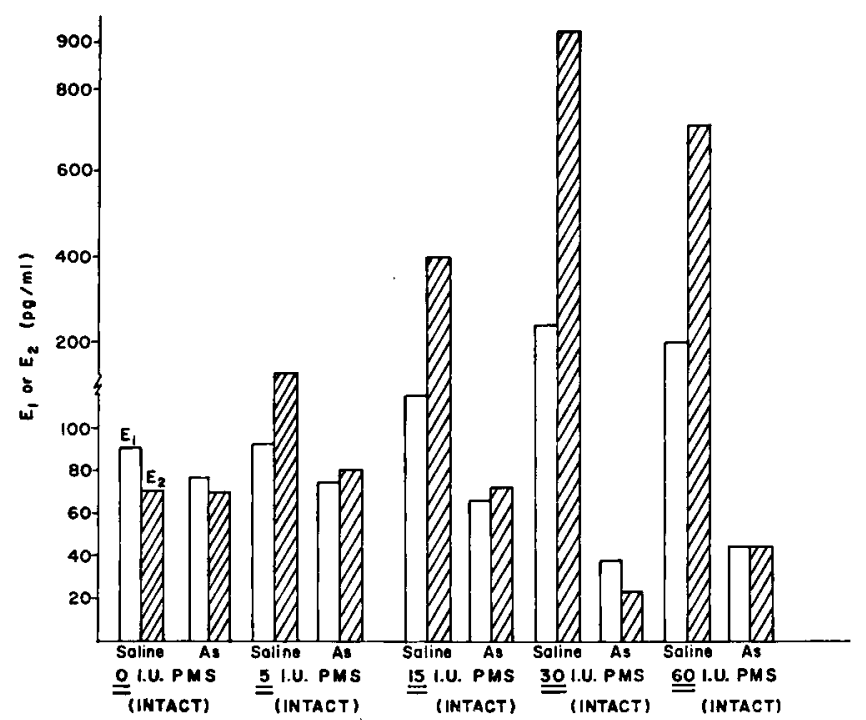

FIG. 3. - Estrone $\left(\mathrm{E}_{1}\right)$ and Estradiol $\left(\mathrm{E}_{2}\right)$ peripheral plasma levels in intact hamsters on day 3 at 1600. Animals were primed with PMS on day 1 and injected IP on day 3 at 0900 with either saline or $25 \mu l$ AS

FIG. 3. - Taux d'cestrone $\left(\mathrm{E}_{1}\right)$ et d'cestradiol $\left(\mathrm{E}_{\mathfrak{g}}\right)$ dans le plasma peripherique chez des Hamsters intacts au $J_{3}$ à 16 heures. Les animaux ont été traités avec $P M S J_{1}$ et ont rę̧u au $J_{3}$ à $9 h$, soit du sérum physio. logique, soit $25 \mu l$ d'antisérum contre PMS. 
that the AS did not affect estrogen levels by I60o in the uninjected controls ; the levels were the same in the saline or AS injected animals. There was a progressive rise in estrogen (especially $E_{2}$ ) with increasing doses of PMS. By seven hours after the injection of AS (atI60o) there was an abrupt drop in peripheral estrogen although all antral follicles still appeared histologically normal. Antiserum given to the 5 or I5 IU PMS treated hamsters, dropped estrogen levels back to control values but in the 30 to 60 IU PMS groups, the AS caused an even more dramatic decline in estrogen.

The above experiment was now repeated in hamsters hypophysectomized at ogoo of day I - the same time of administration of PMS. This procedure, as previously mentioned, eliminates most of the developing follicles from maturing and all the remaining follicles develop under the influence of PMS. It is evident from figure 4 that $\mathrm{E}_{1}$ and $\mathrm{E}_{\mathbf{2}}$ levels were comparable between the saline injected animals,

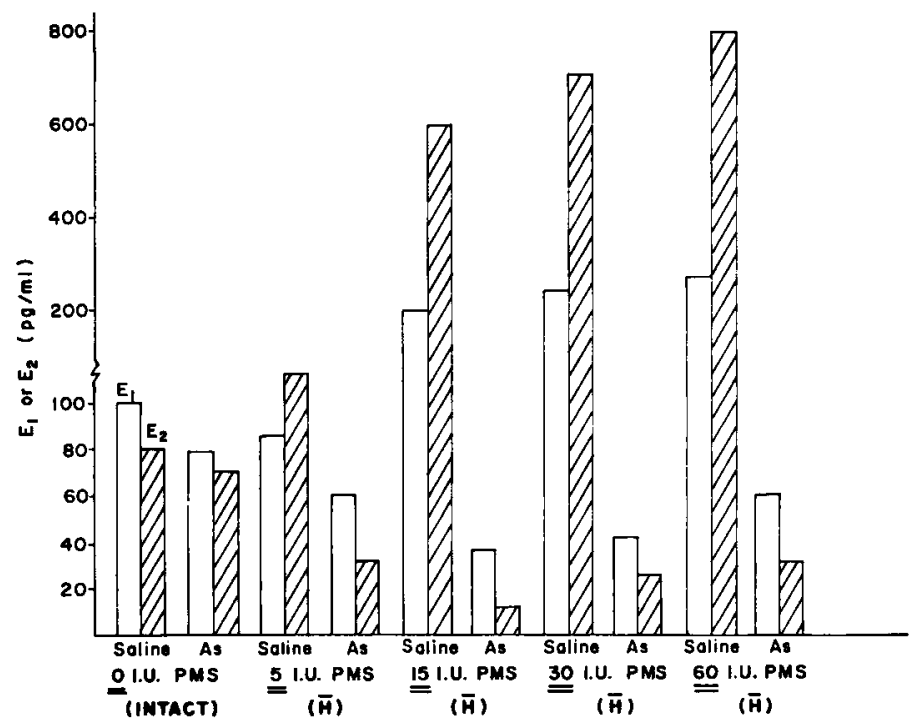

FIG. 4. - Estrone $\left(\mathrm{E}_{1}\right)$ and Estradiol $\left(\mathrm{E}_{2}\right)$ peripheral plasma levels in hypophysectomized hamsters on day 3 at 1600. Animals were hypophysectomized on day 1 at 0900 and immediately injected with PMS. They were injected on day 3 at 0900 with either saline or $25 \mu l$ AS to PMS

Frg. 4. - Taux d'cestrone $\left(\mathrm{E}_{1}\right)$ et d'cestradiol $\left(\mathrm{E}_{2}\right)$ dans le plasma péripheriquechez des Hamsters hypophysectomisés au $J_{3} \dot{a} 16$ heures. Le $J_{1} \dot{a} 9 h$ et injectés immédiatement avec PMS. Ils ont ref̧ $J_{3} \dot{a} 9 h$, soit de sérum physiologique, soit $25 \mu l$ d'antisérum contre PMS.

whether they were hypophysectomized or intact. This indicates that reduced follicular numbers was not reflected in a corresponding decrease in peripheral estrogen. However, when AS was injected on the morning of day $3, \mathrm{E}_{1}$ and $\mathrm{E}_{2}$ levels (especially the latter) plummeted to extremely low values. The estrogen values for the group injected with 5 or I5 IU PMS were now comparable to the values reached in the intact animals primed with 30 or 60 IU PMS.

These results are explained as follows. In the intact hamster injected with I5 IU PMS, both the developing and reserve follicles contribute estrogen to the peripheral levels. When AS is administered on the morning of day 3, early evidence of atresia is provided by a sudden drop in estrogen secretion by the reserve follicles. 
However, the developing follicles are unaffected and their estrogen production is sustained by endogenous gonadotrophins. On the other hand, when higher doses of PMS are administered, increased numbers of reserve follicles begin to mature and estrogen levels are even further elevated. This in turn curtails endogenous gonadotrophins to the extent that the developing follicles produce less estrogen than usual. Therefore, when AS is administered on day 3 - leading to incipient atresia of the reserve follicles - a sharp decline in estrogen is observed.

To return to the question initially raised in this section : does a sudden drop in estrogen account for the lengthening of the cycle when AS is administered on day 3 ? This does not seem to be the explanation since the groups injected with 5 or I5 IU PMS still have estrogen values after AS treatment comparable to the controls. Moreover, the cycle lengthening effects of AS administered on day 3 cannot be reversed by simultaneous injection (SC) of I to $50 \mu \mathrm{g}$ of estrone, estradiol benzoate or estradiol cypionate. Similarly, progesterone $(.5-5 \mathrm{mg})$ was also ineffective in counteracting the actions of the AS. The PMS treated hamster maintains a normal 4 day cycle in the face of extraordinarily elevated estrogen levels (fig. I and 4). It is possible that the sudden drop in peripheral estrogen, following AS administration may alter the sensitivity of the hypothalamic-pituitary axis and delay the release of gonadotrophin releasing factors in the quota necessary to ensure ovulation. Experiments are now in progress to test this possibility.

\title{
ACKNOWLEDGEMENTS
}

This is a contribution from the Research Professorship in Human Reproduction. The research was supported by grants from the N. I. H. (HD-oo596) and the Ford Foundation. I wish to thank N. I. H. for providing the ovine LH and Ayerst for furnishing the PMS. I am especially grateful to Dr. Donald C. Jounson for providing the PMS antiserum.

\section{RÉSUMÉ}

\author{
DISTINCTION ENTRE L,ES FOLLICULES EN DÉVELOPPEMENT \\ ET LES FOLIICULES DE RÉSERVE CHEZ LE HAMSTER CYCLIQUE
}

Des rés altats obtenus antérieurement permettent de dire qu'au début du cycle œstrien $\left(\mathrm{J}_{2}\right)$ du Hamster, chaque ovaire renferme io follicules en développement et 25 follicules en réserve qui peuvent être recrutés par des doses progressives de PMS.

Une injection de I 5 ou 30 UI de PMS à $J_{3}$ empêche l'ovulation des 20 follicules en développement (en combinant les 2 ovaires) tandis que le cycle est allongé à 7 jours.

Si les Hamsters traités par PMS à $\mathrm{J}_{1}$ sont hypophysectomisés à $\mathbf{I} 3 \mathbf{h}$ du $\mathrm{J}_{1}$, Io à 20 follicules sont soustraits à l'ovulation induite par $5 \mu \mathrm{g} \mathrm{LH}$ injectés au $\mathrm{J}_{4}$. Des Hamsters traités de la même manière, mais hypophysectomisés le $\mathbf{J}_{2}$ ovulent à peu près le même nombre d'œufs que les Hamsters intacts traités par PMS. Ce qui permet de penser que l'hypophyse doit rester in situ pendant la plus grande partie du $\mathrm{J}_{1}$ pour stimuler les follicules en développement, mais que, ensuite, ils peuvent être maintenus par PMS.

Un antisérum (AS) contre PMS empêche le développement et la maturation des follicules de réserve quand on fait une injection IP à $J_{1}, 2$ ou 3 du cycle à des Hamsters traités par PMS à $\mathrm{J}_{1}$. L'injection de l'antisérum $\mathrm{J}_{3}$ provoque un retard de un jour dans l'achèvement du cycle.

Un traitement avec I 5 ou 60 UI de PMS provoque une élévation importante des taux d'œestro- 
gènes circulants, mais la durée normale du cycle ( 4 jours) est maintenue avec 15 ou $3^{\circ}$ UI de PMS.

L'injection de AS à $9 \mathrm{~h}$ du $\mathrm{J}_{3}$ à des Hamsters traités avec 30 ou 60 UI de PMS conduit à une réduction importante des niveaux d'œstrogènes. La chute des taux d'œstrogènes n'est pas aussi importante chez des Hamsters intacts ayant reçu I 5 UI de PMS, mais elle est importante chez des Hamsters traités de la même façon et hypophysectomisés. Ce qui permet de penser que les niveaux élevés d'œstrogènes dans le sang périphérique résultent uniquement de l'activité des follicules de réserve.

\section{REFERENCES}

Baranczuk R., Greenwald G. S., I973. Peripheral levels of estrogen in the cyclic hamster. Endocringlogy, 92, 805-812.

GREENWALD G. S., I963. Effect of an anti-PMS serum on superovulation in the hamster. Endocrino$\log y, 73,436-44 \mathrm{I}$.

GreEnWALD G. S., I967. Induction of ovulation in the pregnant hamster. Am. J. Anat., 121, 249-258. GREENWALD G. S., 1972. Experimental manipulation of follicular development in the cycling hamster. In : Currents in Reproductive Biology, J. T. Velardo, ed. : in press. 